\title{
THE BEGINNING AND END OF APPIAN'S MITHRIDATEIOS*
}

\begin{abstract}
This article deals with the structure of Appian's Mithridateios. All the manuscripts begin with two chapters (now numbered 118 and 119) that, in his 1785 edition of Appian, Johannes Schweighäuser argued could not represent the opening of the work: a folio had been removed from its proper place towards the end of the work and mistakenly placed at the beginning. All editors followed Schweighäuser until recently, when there has been a tendency to accept the manuscript order of chapters. This creates a very different start for the work, meaning that it begins with the Greek words $\hat{\omega} \delta \varepsilon \mu \varepsilon$, an impossibly compressed way of saying 'The following book sets out how ... '. By examining the issues involved, particularly the language of Appian and his general practice in structuring the separate works of his Roman History, this article seeks to demonstrate that the Mithridateios cannot have begun as the manuscripts set out. It also argues, however, that the two chapters in question do not fit well at the end of the work, either; and that the reason for this, and for the displacement of the chapters in the first place, is the repetitive summary material at the end of the work. In chapters 118 and 119, it is argued, Appian has used different source material without integrating it properly with what preceded and followed, thus leading to an untidy ending. This was made more orderly by removing chapters 118 and 119 and putting them at the beginning.
\end{abstract}

Keywords: Appian; Mithridateios; manuscripts; folios; Schweighäuser; Budé

There is a major textual, or at least editorial, problem at the beginning of Appian's study of the Mithradatic Wars. All the manuscripts begin with two chapters that have, since the intervention of the great German scholar Johannes Schweighäuser, almost always been repositioned near the end of the work as chapters 118 and 119 (579-89). ${ }^{1}$ Chapter 118 contains a summary of the additions made to the Roman empire as a result both of the Mithradatic Wars directly and of the impetus they created for further Roman expansion: it was a 'great' war and Pompey was called 'the Great' because of the number of imperial acquisitions, the duration of the struggle and the endurance of Mithradates himself. Chapter 119 then summarizes the extent of Mithradates' power and alliances (including the pirates), and his determination to embroil the whole world in war. Such a wide scope made it impossible for Appian to treat the subject

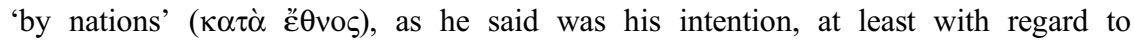
Rome's foreign enemies, in the preface to the whole work. ${ }^{2}$ For Schweighäuser, it seemed so obvious that these chapters belonged to an epilogue rather than to an exordium that he did not argue the point at length: a folio was moved from its proper

\footnotetext{
* I am grateful to the $C Q$ reader who saved me from errors and made astute suggestions.

1 J. Schweighäuser, Appiani Alexandrini Romanorum Historiarum quae supersunt (Leipzig, 1785), 1.642 .

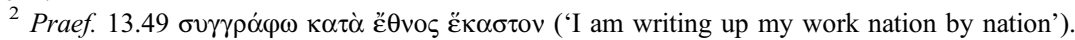

(C) The Author(s), 2021. Published by Cambridge University Press on behalf of The Classical Association. This is an Open Access article, distributed under the terms of the Creative Commons Attribution-NonCommercial-ShareAlike licence (https://creativecommons.org/licenses/by-nc-sa/4.0/), which permits non-commercial re-use, distribution, and reproduction in any medium, provided the same Creative Commons licence is included and the original work is properly cited. The written permission of Cambridge University Press must be obtained for commercial re-use. 
place and mistakenly put at the beginning. ${ }^{3}$ I believe Schweighäuser was right, but the matter is perhaps not as straightforward as he made out, and some contemporary scholars accept the manuscripts as they stand, most prominently the Budé edition of Paul Goukowsky. ${ }^{4}$

For all the manuscripts, without exception, to have got the beginning of the work wrong, the folio would have to have fallen out, or been removed, from the end and placed at the beginning, before the surviving medieval copies were made. Our earliest manuscripts of the Mithridateios, however, are from the fifteenth century, allowing plenty of time for something to have gone wrong. Although the material contained in the passage would, as Goukowsky points out, ${ }^{5}$ fortuitously have to have been exactly the length of a folio, the two chapters in question do fill close to a folio of Vat. gr. 2156, for example, and appear to contain neither too much nor too little material to rule out the possibility of exactly filling a folio. That folios can lose their moorings and disappear altogether is evident. That they should reappear in the wrong place is unlikely when they contain text, but possible. ${ }^{6}$ The most famous example of such a transposition occurs in Book 4 of Lucretius, where a leaf of the archetype was disbound and inserted the wrong way round, with the result that in the manuscripts lines 299-322 occur after lines 323-47. ${ }^{7}$ In the case of Achilles Tatius' Leucippe and Clitophon, too, one explanation for a considerable deviation in the narrative order between the papyri and the manuscripts of the text has always been that 'a leaf in the archetype from which the medieval manuscripts were derived was copied in the wrong position' ${ }^{8}$ And, as has long been observed, manuscripts A and B of Persius' Satires have the choliambic prelude at the end, rather than, like the other manuscripts, at the beginning. ${ }^{9}$ This is not, to be sure, a matter of wandering folios, but it is interesting to note an uncertainty in the manuscripts about whether these verses constitute a beginning or an ending. Cases like this do little more than suggest that Schweighäuser's contention is possible, but other considerations provide stronger reasons to believe that it is correct.

The main problem with what might seem to be the reasonable course of following the unanimous manuscript order is that the work would then start with the Greek words $\hat{\omega} \delta \varepsilon \mu \varepsilon \dot{v}$. Goukowsky rightly, but uncritically, points out that $\hat{\omega} \delta \varepsilon$ can refer to

\footnotetext{
3 'One egg could scarcely be more similar to another' (vix autem rursus ovum ovo similius est), he writes, than the epilogues of the African or Syrian Books are to these two chapters of the Mithridateios: see J. Schweighäuser, Exercitationes in Appiani Alexandrini Romanas Historias (Strasbourg, 1781), one of his short works, handily collected as Opuscula Academica (Strasbourg, 1806), 21-2, 52-5.

${ }^{4}$ See the German translation of O. Veh and K. Brodersen, Appian von Alexandria. Römische Geschichte, erster Teil: die römische Reichsbildung (Stuttgart, 1987), 330; P. Goukowsky, Appien, Histoire Romaine, Tome VII, Livre II: la Guerre de Mithridate (Paris, 2001), vi-xii. In the new Loeb edition of Appian I accept Schweighäuser's transposition: B.C. McGing (ed.), Appian. Roman History (Cambridge, MA and London, 2019-20), 3.146-7.

${ }^{5}$ Goukowsky (n. 4), viii n. 3.

${ }^{6}$ It is easy to understand how we cannot be sure that the single page pictures of the Book of Kells, no doubt produced as a separate activity, are in their correct place: C. de Hamel, Meetings with Remarkable Manuscripts (London, 2016), 129.

7 D. Butterfield, 'Lucretius auctus?', in J. Martinez (ed.), Fakes and Forgers of Classical Literature. Ergo decipiatur! (Leiden, 2014), 15-42, at 31 n. 55. K. Lachmann was the first to correct the error: H.A.J. Munro, T. Lucreti Cari De Rerum Natura libri sex (Cambridge, 1866 ${ }^{2}$ ), 1.29.

${ }^{8}$ See the commentary by B.P. Grenfell and A.S. Hunt on P.Oxy. 1250; also L.B. Mortensen and T. Eide (edd.), Tomas Hägg. Parthenope: Selected Studies in Ancient Greek Fiction (Copenhagen, 2004), 195.

${ }^{9}$ H.N. Parker, 'Manuscripts of Juvenal and Persius', in S. Braund and J. Osgood (edd.), $A$ Companion to Persius and Juvenal (Malden, MA / Oxford / Chichester, 2012), 137-61, at 159.
} 
what follows. ${ }^{10}$ It occurs two hundred and nine times in the surviving works of Appian, just over forty of them looking forward, the rest referring solely to what has preceded. In the majority of these forward-looking examples, they refer simply to a speech or

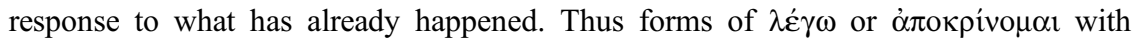
$\hat{\omega} \delta \varepsilon$ occur twenty times. ${ }^{11}$ In these cases, and even when the word introduces a longer narrative, however, it is important to note that, in Appian at least, it cannot refer forwards without also looking back: it does not initiate a narrative unassisted, so to speak. ${ }^{12}$ Thus, for example, when Appian introduces the elaborate story of how Glaucia, Saturninus and Marius worked together to have Quintus Caecilius Metellus

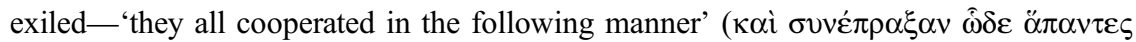
$\dot{\alpha} \lambda \lambda \dot{\eta} \lambda$ ors, B Civ. 1.29.129)—he had already opened the account with a statement that Glaucia and Saturninus forced Metellus into exile by enlisting the support of Marius; $\hat{\omega} \delta \varepsilon$ then explains how it was done. Similarly with the assassination of Viriathus (Hisp. 74.311-16). Viriathus' most trusted associates, instead of negotiating with Quintus Servilius Caepio, accepted the latter's bribes and undertook to kill their leader,

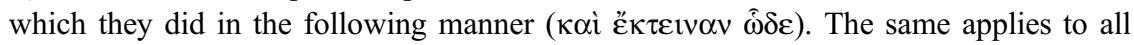
occurrences of $\hat{\omega} \delta \varepsilon$ when it refers to what follows. If we accept the manuscripts, $\hat{\omega} \delta \varepsilon$ at the beginning of the Mithridateios would have to mean, in unprecedented fashion for Appian, something like this: 'what follows in this book is the story of how ...'. Furthermore, $\hat{\omega} \delta \varepsilon \mu \varepsilon \dot{\varepsilon}$ occurs fifty-seven times in Appian, without exception to summarize what has preceded, not what follows. Schweighäuser drew attention to the similarity of the epilogues in the Libyke (= Pun.) and Syrike (= Syr.) and Mithridateios (= Mith.):

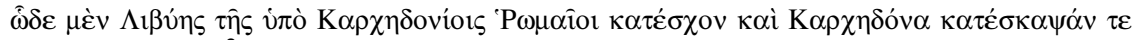

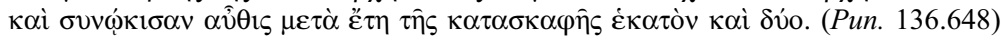

This is how Rome came into possession of that part of Africa ruled by the Carthaginians, razed Carthage to the ground, and refounded it, one hundred and two years after they had destroyed it.

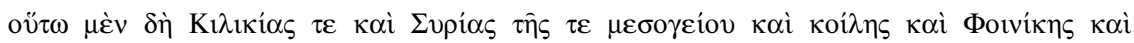

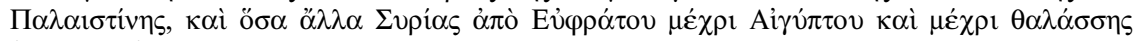

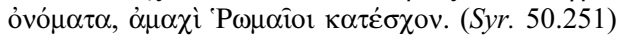

In this way, and without fighting, the Romans came to possess Cilicia and inland Syria and Coele Syria and Palestine and all the regions of Syria bearing other names between the Euphrates, Egypt and the Mediterranean.

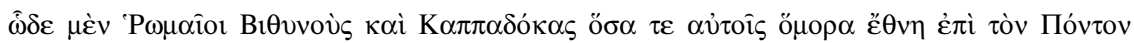

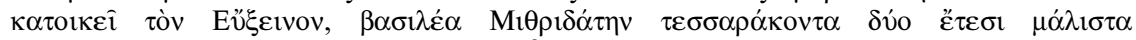

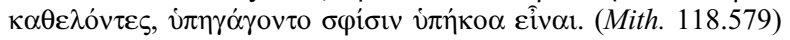

This was how the Romans, after taking some forty-two years to destroy King Mithridates, brought under their rule Bithynia, Cappadocia and all their Pontic neighbours living on the shore of the Euxine sea.

It is all but impossible to see how the formulation of chapter 118 could begin the Mithridateios.

${ }^{10}$ Goukowsky (n. 4), 1 n. 1.

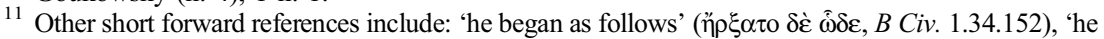

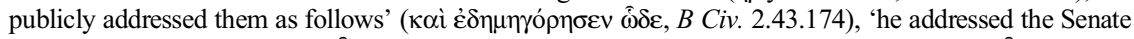

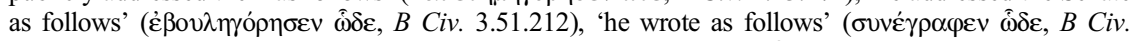

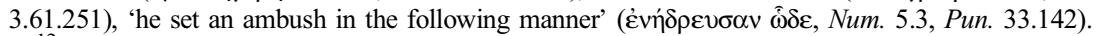

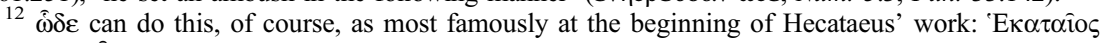
Mı $\lambda \dot{\sigma} \sigma \iota \varsigma \hat{\omega} \delta \varepsilon \mu \nu \theta \varepsilon i \tau \alpha \iota$ (fr. 1 Fowler). 
It is also the case that Appian is more than capable of summarizing the contents of a book at its beginning in perfectly clear language. The Hannibalic Book, for example,

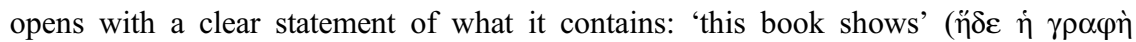
$\delta \eta \lambda$ ô, Hann. 1.1). Similar language is used at the beginning of the second book of

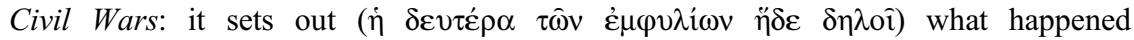
after Sulla, how Caesar destroyed Pompey and was himself then assassinated. In Civil Wars Book 3 Appian opens with a brief look back at what he had covered in Book 2-'Such is the story of how Gaius Caesar, who performed exceptional service for the Romans with regard to their empire, was killed by his enemies and buried by

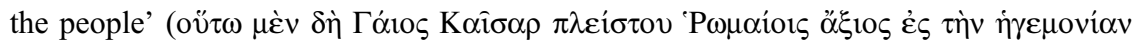

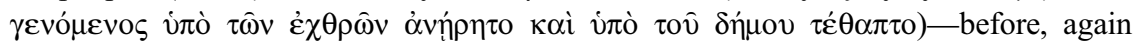
briefly, summarizing what is to come: 'All of his murderers received their punishment, and this book and the one after it will show how this came about for the most

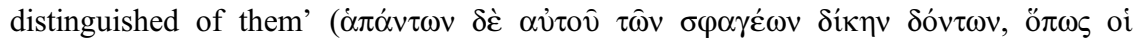

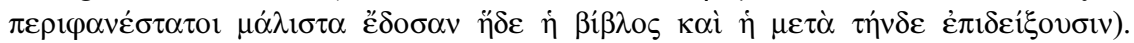
There is the same clear backward and forward glance at the beginning of Book 4: the preceding account (Book 3) tells how Trebonius and Decimus met their punishment; how Brutus and Cassius got their comeuppance, this fourth book sets out ( $\dot{\eta} \tau \varepsilon \tau \dot{\alpha} \rho \tau \eta$

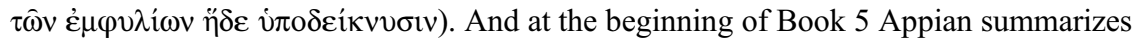
the story he is going to cover and then starts the narrative: 'the details of these events are

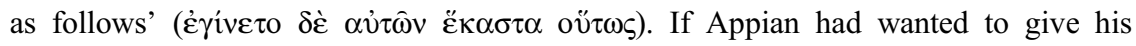
audience a preview of the contents of the Mithridateios, he had the language and the technique to do so with simple clarity; nowhere else does that include starting with an abrupt and elliptical $\hat{\omega} \delta \varepsilon \mu \varepsilon \dot{v}$.

Removing the two chapters to the end of the work also has the advantage that the Mithridateios would then start in the same manner as the Illyrike, both sentences starting with exactly the same structure:

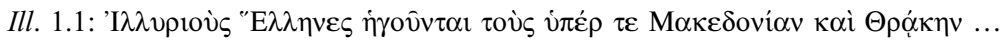

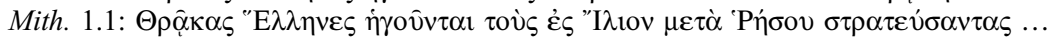

The similarity is striking. And both books cover much the same sort of introductory material-geography, name, origins-as the prefaces to the Libyke and the Iberike. If we are not quite justified in calling this standard practice for Appian, there does seem to be a pattern of openings. ${ }^{13}$ Perhaps even more significant is the absence of a connective particle at the start of both sentences, an absence found in Appian at the beginning of his separate books. There is no connective particle at the beginning of the first sentence of the Praefatio, Iberike, Libyke, Illyrike, Syrike and Book 1 of the Civil Wars. ${ }^{14}$ The only exception (among the fully preserved books) is the Hannibalic Book, which has the particle $\delta \dot{\varepsilon}$ at the start of the first sentence. The

${ }^{13}$ For geography turning up at the start of Appian's books, see L. Pitcher, 'Appian', in I. de Jong, Space in Ancient Greek Literature. Studies in Ancient Greek Narrative (Leiden, 2012), 219-33, at 229-30.

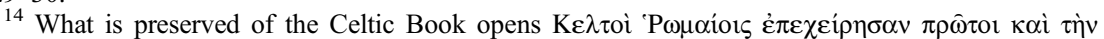

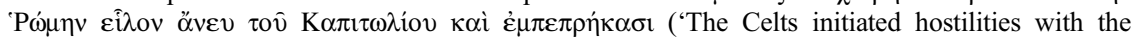
Romans, capturing and burning Rome itself, all except the Capitol'). It is usually assumed that there was an introductory chapter before this-see A. Hofeneder, Appians Keltike: Einleitung, Text, Übersetzung und Kommentar (Vienna, 2018), 21-but, in view of the absence of a connective, these may well be the opening words of the work. 
remaining books of the Civil Wars all make a link with the preceding book, and therefore have a connective particle in the first sentence. There are other examples of asyndeton at the beginning of Appian's sentences. When ö $\theta \varepsilon v$ is the first word of a sentence, for example-it occurs ninety-two times in that position-it almost never has a connective. ${ }^{15}$ The same applies to the adverb ei $\tau \alpha$, and Appian has a strong tendency to have no connective when a relative or demonstrative pronoun begins a sentence. ${ }^{16}$ For an author who wrote Greek with some care, and whose prose is, as one would expect, replete with connective particles, none of this is accidental. ${ }^{17}$ The lack of a connective at Mith. 1.1 is at least a strong indication that we are at the beginning of the book.

Goukowsky recognizes patterns in Appian's prologues and epilogues, but regards the Mithridateios as so different from other books that the reader needs to be notified of this in the explanatory preface with which the manuscripts start, rather than at the end of the work. ${ }^{18}$ But just how different is the Mithridateios? As Christopher Pelling has observed more than once, programmatic statements are often little more than a writer's opening bid, and may not prove a reliable guide to his work. ${ }^{19}$ Appian clearly did not feel tightly restricted by his stated intention to write about Rome's foreign conquests 'by nations'. Straightaway, although the first three books concern the rise of Rome in Italy, the Basilike just recounts what happened in the time of the seven kings: it is much more a chronological than a strictly 'national' organizing principle. The same applies to the Hannibal, which, given the problems posed by the many different theatres of the Second Punic War, is understandably centred on the person of Hannibal and the war in Italy. The title announces its difference, as do the Basilike, the Hundred Years

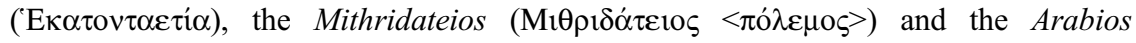

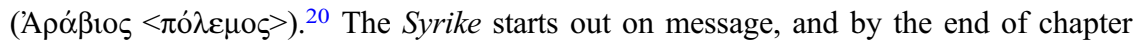
51 seems to have fulfilled its task perfectly, having narrated the history of how Syria came under Roman control. But then Appian claims: 'It is not out of place to run through its history in the time of the Macedonians, who ruled it before Rome' (oủ

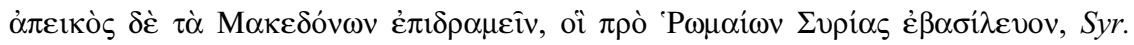
52.260). It is, on the contrary, completely out of place, quite unnecessary for understanding how the region became part of the Roman empire. By the time he comes to the end (Syr. 70.369), Appian seems to admit that it is not the subject of

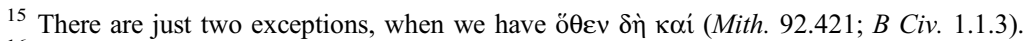

${ }^{16}$ Ei $\tau \alpha$ begins a sentence twelve times, never with a connective; $\hat{\omega} v$ occurs one hundred times as the first word of a sentence, and I count only seven instances where it has a connective particle: $\hat{\omega} v$ with

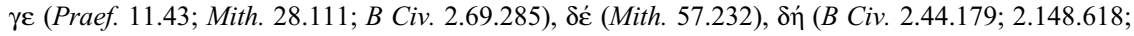
5.50.209).

${ }^{17}$ For the care with which Appian wrote, see G.O. Hutchinson, 'Appian the artist: rhythmic prose and its literary implications', $C Q 65$ (2015), 788-806. One might also note the approval of the ninth-century scholar Photius (Bibl. 57 17a), who regarded Appian's style as lean (i $\sigma \chi v o ́ \varsigma$ ) and

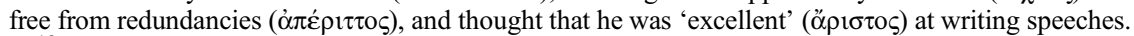

${ }^{18}$ Goukowsky (n. 4), viii-xii.

19 C. Pelling, 'Causes in competition: Herodotus and Hippocratics', in E. Bowie (ed.), Herodotus. Narrator, Scientist, Historian (Berlin, 2018), 199-222, at 199; C. Pelling, 'Plutarch's adaptation of his source-material', JHS 100 (1980), 127-40, at 139=id., Plutarch and History (Swansea, 2002), 91-115, at 106 .

${ }^{20}$ I am making the assumption that the titles we have of Appian's books are the ones he gave them. In general this seems justified, certainly for the Mithridateios and the works I have just cited, but there are uncertainties about some of the other books. The main evidence for the names of Appian's books is conveniently tabulated by $\mathrm{K}$. Brodersen, 'Appian und sein Werk', $A N R W$ 2.34.1 (Berlin and New York, 1991), 339-63, at 342-3. 
this book. The Mithradatic Wars must have posed organizational problems similar to those of the War against Hannibal: they were conducted in widely dispersed areas of the Mediterranean. Theoretically, as with the Second Punic War, it might have been possible to divide the subject into its constituent geographical parts-Pontic, Bithynian, Cappadocian, Asian, Ionian, Greek, Macedonian, Iberian, Armenian—but there were just too many of them, and the story would have lost all cohesion. It started out normally, however, with a challenge to Rome emerging in northern Asia Minor, which calls for the introduction we get on Bithynia and Cappadocia (Mith. 1.1-9.29). Although the First Mithradatic War spreads out over the whole of Asia Minor, and into the Mediterranean islands, Macedonia and Greece, the war ends with Mithradates confined to his kingdom, and up to that point the book could convincingly still have had a provisional title such as the Bithynian and Cappadocian Book of Roman

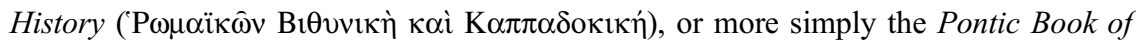

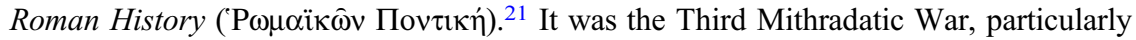
Pompey's campaigns, that rendered such titles inadequate, extending the results of the conflict into far-flung areas. The scope of what Appian covers, then, becomes wider than in other books, but the purpose and the outcome remain the same: the work explains how the Mithradatic Wars extended Roman rule, rather than in just one area, 'from the setting of the sun to the river Euphrates' (Mith. 119.588). And Appian adds that, although the nature of the material made it impossible to treat each nation individually in all cases, he did divide it up nationally where he could do so: 'it was not possible for me to divide up this story strictly nation by nation, as everything happened at the same time and was interconnected. But, even so, where it was possible

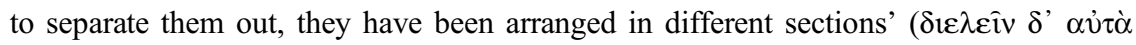

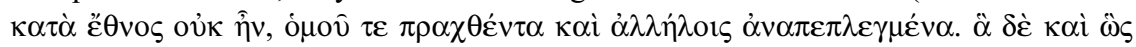

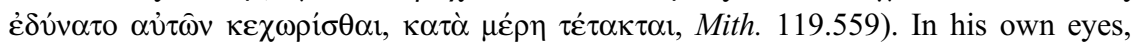
the Mithridateios did not seem that different from what he had done in other books.

Although chapters 118 and 119 cannot begin the work, and Schweighäuser put them in the only place they fit towards the end of the Mithridateios, part of the reason the folio dropped out, or was removed, in the first place may be the nature of the material at the end of the work: there seem to be too many summaries. Mithradates dies at Mith. 112.540, and Appian logically uses the event to present a brief review of the king's life and career. The account proceeds chronologically from Mithradates' descent from Darius, through his early victories over his neighbours, and then his forty-year war with Rome, ending in his death. We hear exactly the sort of thing to be expected in an obituary notice: the lands he conquered, the huge armies he commanded, the generals he fought against, his allies, his larger-than-life character, his physique and his cultural tastes. The chapter concludes as follows: 'Such was the end of Mithridates, surnamed

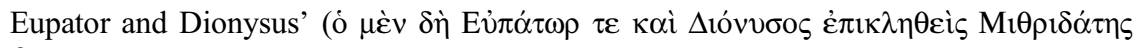
$\hat{\omega} \delta \varepsilon \varepsilon \dot{\varepsilon} \tau \lambda \varepsilon \varepsilon \dot{\tau} \tau \alpha$, Mith. 113.551). There could hardly be a clearer statement wrapping up Mithradates' reign and personal story.

Rome is delighted at the news, Pharnaces sends his father's body to Pompey with a request that he be allowed to rule the kingdom, or just Bosporus, and the focus now shifts to Pompey's actions and achievements. He makes Pharnaces a friend and ally of Rome, and appoints him ruler of Bosporus (Mith. 113.554-5). Having defeated the

${ }^{21}$ Indeed Schweighäuser (n. 3), 21 thinks it might have been known as Historia Pontica, since one

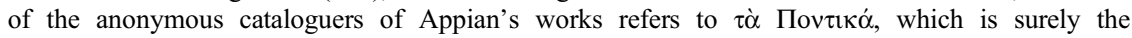
Mithridateios. 
pirates, destroyed Mithradates and fought against innumerable enemies, he had extended the Roman empire as far as Egypt (Mith. 113.556). We hear how Pompey treated his various opponents, what appointments he made, the towns he founded, or restored, and the treasures he collected (Mith. 114.558-115.564). This leads naturally into an account of what he did with all this wealth, and particularly how he displayed it, his royal prisoners and the highlights of his victories in a magnificent triumph in Rome (Mith. 116.565-117.578).

Up to this point, Appian has been winding down the dramatic story of the Mithradatic Wars in a well-structured summary that effectively conveys the scale of the struggle and the importance of the victory, and we have now reached the obvious place to bring the book to an end, in the way that Mith. 118.579 promises. Appian wants to finish by saying something about the consequences of the conflict from the perspective of Rome, having already done so from that of Mithradates and Pompey. It sets out in the right direction, but repetition begins to creep in. It had taken Rome forty-two years to destroy Mithradates and annex Bithynia, Cappadocia, their Pontic neighbours and the interior of Syria up to the river Euphrates (Mith. 118.580). We have already been told that Pompey extended the frontier of the empire to the Euphrates (Mith. 116.568), and we are to hear it again at Mith. 119.588 and 121.599. Mithradates had seized a number of areas that were easily recovered and made tributary to Rome. In addition to Bithynia and Cappadocia, there was Paphlagonia, Galatia, Phrygia, Mysia, Lydia, Caria, Ionia, the region of Pergamum, old Greece and Macedonia (Mith. 118.581). In his review of the king's career, Appian had already mentioned his conquest of Bithynia, Cappadocia, Asia, Phrygia, Paphlagonia, Galatia, Macedonia and Greece (Mith. 112.542). The Romans called the war and their commanding general, Pompey, 'Great', because they made so many additions to their empire, because it took so long, forty years, and because of the courage and endurance of Mithradates himself ( We have just been told that the war lasted forty-two years (Mith. 118.579), and in chapter 112 Appian had mentioned both the forty-year war (Mith. 112.542) and Mithradates' endurance ( back Mithradates centre-stage. It does not go over exactly the same ground as chapter 112, but concentrates just on his power and allies. There is some overlap of information-at Mith. 112.546 we had been told that the king made alliances with the Samnites and the Celts, and sent a mission to Sertorius in Iberia, while now he is recorded as sending a mission to those who were stirring up revolt against Rome in Iberia, and establishing friendly relations with the Celts (Mith. 119.585) — but what is strange is the return to Mithradates at all, when we seemed to have finished with him so definitively at Mith. 113.551.

The acquisition of the Pontic kingdom was not quite complete with the death of the king, since Pharnaces continued to resist Rome. Chapter 120 finishes his story, bringing Pontic resistance to an end, and chapter 121 briefly rounds off the whole book to tell us

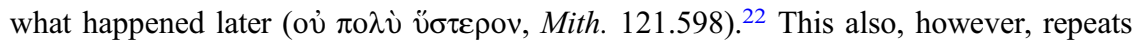
the information that the empire now stretched to the Euphrates and, even more noticeably, that the victory and the commanding general were called 'Great' (Mith. 121.599). Appian has only just dealt with this three chapters earlier (Mith. 118.582).

22 Appian makes the same brief forward glance at the end of other works: see Pun. 136.644 ( $\chi \rho \cos \omega$

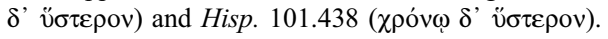


Although modern scholarship now recognizes Appian as an author who did conceive and write his own work of history, rather than just unthinkingly cobble together bits of other historians' works, one of the obvious explanations for what we get in chapters 118 and 119 is that Appian was using material from a different source and had not properly integrated it with the chapters that precede and follow. ${ }^{23}$ The transition from the end of chapter 117- 'Such was Pompey's

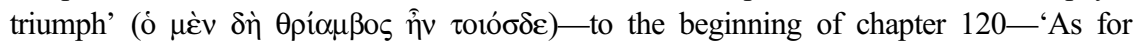

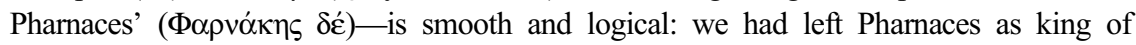
Bosporus (Mith. 114.554-5) and need to hear what happened to him and, briefly, to the region. We do not obviously need chapters 118 and 119 , although that is not to say that they are superfluous, as they contain new summary material and Appian's own thinking on the nature of the Mithradatic Wars. They seem rather to be part of an untidy end to the work, in which Appian has not edited his source material satisfactorily. Past generations of scholars quickly attributed any such failings they found in Appian to incompetence, but the possibility should be kept in mind that the Roman History was unfinished when Appian died. ${ }^{24}$ There is no trace at all of the Parthian book or of the final one on the resources of Rome, both of which he planned (Syr. 52.260; Praef. 15.61). And while the extremely uneven distribution of speeches in the work could just be a reflection of what he found in his sources, it also seems possible that he had not finished his editorial work. ${ }^{25}$ This is not an argument for supporting the order of the manuscripts, but it might help to explain why these chapters dropped, or were taken, out of their place at the end of the work and incorrectly put at the beginning.

In the preface to the first volume of his commentary on Polybius, Walbank praises the thoroughness and sound common sense of Schweighäuser's commentary: 'Again and again', Walbank wrote, 'Schweighäuser is right where his successors are wrong. ${ }^{26}$ Schweighäuser was, I believe, also right to think that the chapters with which the manuscripts of Appian's Mithridateios begin cannot have constituted the beginning of the work, and he replaced them where Appian had written them.

Trinity College Dublin

BRIAN MCGING bmcging@tcd.ie

23 The best demonstration of current trends in Appianic scholarship will be found in K. Welch (ed.), Appian's Roman History. Empire and Civil War (Swansea, 2015). For the most convincing analysis of Appian's working methods and how he used his sources, see J. Rich, 'Appian, Polybius and the Romans' war with Antiochus the Great: a study in Appian's sources and methods', in K. Welch (ed.), Appian's Roman History. Empire and Civil War (Swansea, 2015), 65-124; id., 'Appian, Dio and Seneca the Elder', in M. Scappaticio (ed.), New Perspectives on Early-Imperial Roman Historiography (Leiden, 2020), 329-54.

${ }^{24}$ Fundamental to any discussion of Appian's conception of his work and how it might have changed in the course of composition is G.S. Bucher, 'The origins, program and composition of Appian's Roman History', TAPhA 130 (2000), 411-58.

${ }_{25}$ There are no formal speeches in the Iberian and Hannibalic books but a number of major oratorical exchanges in the very next book, the Libyke (the debate at Rome, for instance, at 57.248-64.288, or the speeches of Censorinus and Banno at 83.386-89.422); and apart from one brief exception there are no speeches in the first book of Civil Wars but a heavy concentration in Books 3 and 4. For the argument that where there are no speeches there were none in the sources Appian was using, see I. Hahn, 'Appian und seine Quellen', in G. Wirth (ed.), RomanitasChristianitas (Berlin, 1982), 251-76. Others see Appian as much more in strategic control of his composition, adapting or inventing speeches where he wanted them: B. Hopwood, 'Hortensia speaks: an authentic voice of resistance?', in K. Welch (ed.), Appian's Roman History. Empire and Civil War (Swansea, 2015), 305-22, at 307.

${ }^{26}$ F.W. Walbank, A Historical Commentary on Polybius (Oxford, 1957-79), 1.vii. 